\title{
Diversity of local food crops in Central Java
}

\author{
Vina Eka Aristya*, and Agus Supriyo \\ Assessment Institute for Agricultural Technology of Central Java, Ministry of Agriculture, Jl. \\ Soekarno-Hatta Km. 26 No. 10, Bergas, Central Java, 50552, Indonesia
}

\begin{abstract}
Food needs serious handling in responding to the challenges of environmental changes and population growth. The diversity of local food crops has the advantage as a source of nutrition and breeding materials. The research aims to determine diverse local food crops in Central Java. A total of 120 farmers were selected by purposive random sampling from Tegal, Brebes, Banjarnegara, and Karanganyar regency, based on different agro-ecological sequences. The field inventory found 257 varieties of 11 types of exotic crops. The compositions of local rice varieties (Indica and Javanica) included seven red rice, nine black rice, 27 white rice, 17 glutinous rice, one animal feed rice, three upland rice, and eight aromatic ones. The frequency of the species distribution rate proves was very narrow in Tegal-Brebes, limited in Banjarnegara, and spread evenly in Karanganyar. The Shannon Diversity Index revealed the diverse species in a region. Banjarnegara had the highest species abundance index. The relationship between the Shannon Diversity Index and Equitability Index illustrates the dominant types of local food plants, especially in Karanganyar dominated by rice. The Sorensen Similarity Coefficient was used to estimate the level of structural similarity between species and regions. Tegal-Brebes have similar species composition and agroecological.
\end{abstract}

\section{Introduction}

The food security challenge is becoming more relevant on the global agenda with increasing food demand and malnutrition. Food availability and accessibility need a driver, especially in developing countries through asymmetric agricultural systems involving subsistent farmers. Existing local agriculture can give crop diversity, hold down agricultural expansion, and diversify the economy [1]. Changes that transform productive agricultural land use and increased population growth are also a concern for rural development goals for sustainable food fulfilment [2].

An important part of food security consists of fulfilling food security which refers to the balance between production, population, and environmental balance. Food accessibility is related to household capacity is understood as households' ability to get enough staple food intake, sufficient nutritional food consumption, and food stability [3].

In the scientific literature, meanings of local food crops are related to domains of proximity geographical, relational, and values. Geographical dimension proximity consists

*Corresponding author: vinaaristya@gmail.com 
of physical locality, the distance between food production, and consumption. Relational proximity of local food crops e.g. close relationship between actors within the food system. The other additional feature is proximity in values which consists of a place of origin, traceability, freshness, and quality [4].

The local food crops have a function to feed the world's growing population depends. The ability of future local food crop supplies able to meet food demand [5]. The diversity of local food plants is a source of nutrition, has genetic potential, and has the advantage of adaptation to specific environments [6].

The continuous and widespread introduction of new varieties can risk genetic erosion, fragmentation, and depletion of the natural population of local genotypes. New varieties and local varieties need harmony to meet food needs and protect local habitats. The local varieties population needs to be maintained to conserve biodiversity and support genetic sources' potential. Systematic control of local food plant populations is considered as a step capable of overcoming food problems [7]. Indonesian national policies on food on mandate security Presidential Decree 22/2009 to the acceleration of food diversification based on local resources. Recommendation for local government to revive local food come from local food crops.

Complex ecological interactions characterize agricultural landscapes. The environmental balance schemes were developed to cut the negative impacts of modern agriculture on biodiversity. The local food crops that be one of the valuable components to urgently protected from extinction and erosion of the genetic potential. Genetic resources in agriculture have been and will continue beneficial for local, national, and global communities' survival and well-being [8]. The wealth of genetic diversity is carried out on agricultural land through an in-situ strategy and equipped with preferential guidance on exsitu protection. This conservation seeks to keep up superior local genotypes with local adaptation to biotic and abiotic pressures [9].

Central Java has rich local food crops, with the potential to food supply and tolerate climate change. Research on the diversity of local food plants in Central Java is very important. This considering the projection showed the field area in Java-Bali will reduce 182,556 ha in 2050 [10]. The main target for identifying the local food crops resources is essential to know the composition, distribution, and diversity. Locally food-based strategies can encourage the local plant and increase sustainable dietary diversification among rural communities [11].

The program for the management, preservation, and use of local genotypes requires information on the diversity of local varieties in each region. This information is very important as the basis for policy formulation to meet sustainable food needs. The objective of the study was to determine diverse local food crops in Central Java (Tegal, Brebes, Banjarnegara, and Karanganyar regency).

\section{Materials and methods}

The study was conducted on farmers' land in four Regencies in Central Java i.e. Tegal, Brebes, Banjarnegara, and Karanganyar. At each site, 30 farmers 'lands were selected in different agro-ecologies by purposive random sampling so that there were 120 farmers' lands in total. Farmers were selected based on ownership of local crop varieties and distance from the regency capital. This research was carried out from March to June 2014. The characteristics of each region were shown in Table 1.

The field survey, exploration, and inventory activities covered various local food plants in the selected farmers' dry land, yard, and rice fields. Each sample of a food crop variety was inventoried and identified. Inventory is to record the type, number, origin, and use of plant species grown on farmer's land. Identification was carried out to find the level of 
genetic erosion of each variety. Some varieties are then collected and rejuvenated in experimental gardens.

Table 1. The characteristics of each region inventoried in Central Java

\begin{tabular}{|l|c|c|c|c|}
\hline \multicolumn{1}{|c|}{ Region } & Altitude (masl) & $\begin{array}{c}\text { Temperature/ } \\
\text { year }\left({ }^{\mathbf{O}} \mathbf{C}\right)\end{array}$ & $\begin{array}{c}\text { Rainfall } \\
(\mathbf{m m} / \mathbf{y e a r})\end{array}$ & Soil Type \\
\hline Tegal & $135-949$ & $27-28$ & 1,313 & Alluvial \\
\hline Brebes & $500-800$ & $26-33$ & 3,327 & Alluvial \\
\hline Banjarnegara & $100-1,000$ & $20-26$ & 3,000 & Latosol \\
\hline Karanganyar & $90-2,000$ & $22-31$ & 5,966 & Latosol \\
\hline
\end{tabular}

The implementation of activities to identify the sample of food crops and to differentiate local and introduced food crops use guidelines from the Ministry of Agriculture [12]. Specific descriptions per food crop commodity used guidelines from IPGRI (International Plant Genetic Resources Institute) and UPOV (The Union for the Protection of New Varieties of Plants).

Each sample of food crop varieties was identified and recorded. Data analysis was performed to determine the diversity of varieties, by calculating the Shannon Diversity Index, Equitability Index, and Sorensen Similarity Coefficient. Shannon Diversity ( $\left.H^{\prime}\right)$, Index and Equitability Index $(\mathrm{EH})$ used to determine the diversity of plants in an area is formulated as follows [13]:

$$
\begin{aligned}
& H^{\prime}=-\sum \begin{array}{c}
S \\
\text { l } \ln p i, \text { and } E H=H^{\prime} \ln S
\end{array} \\
& i=1
\end{aligned}
$$

$\mathrm{H}^{\prime}=$ the Shannon Diversity Index,

$\mathrm{pi}=$ proportion of plants to-i,

$\mathrm{EH}=$ Equitability Index,

$\mathrm{S}=$ the number of plant species in a region

The Sorensen Similarity Coefficient analysis was used to estimate the level of structural similarity between plant species between two regions [14]. The Sorenson coefficient (SC) was estimated by the following formula.

$$
S C=2 C / S_{1}+S_{2}
$$

$\mathrm{SC}=$ the Sorenson Coefficient,

$\mathrm{C}=$ the number of similar plant species,

$\mathrm{S}_{1}$ and $\mathrm{S}_{2}=$ the total number of plant species in regions 1 and 2

\section{Results and discussion}

A systematic study to determine the diversity of local food plants in Central Java resulted in inventory data and the level of local food plant diversity in Central Java.

\subsection{Inventory of local food crops in Central Java}

Based on the inventory results, 257 varieties of 11 types of exotic local food plants were recorded. They consisting of rice, cassava, taro, sweet potato, soybean, corn, Dioscorea tuber, canna, and arrowroot. In addition, there were 72 varieties of rice (Oryza sativa) as local food that was still widely cultivated in Tegal, Brebes, Banjarnegara, and Karanganyar. Other commodities are cassava (Manihot utilissima) (49), taro (Colocasia esculenta) (37), sweet potato (Ipomoea batatas) (24), soybean (Glycine max) (16), corn (Zea mays) (15), 
sweet potato (Dioscorea alata and Dioscorea esculenta) (22), Amorphophallus campanulatus (9), canna (Canna edulis) (7), and arrowroot (Marantha arundinaceae) (6) (Fig. 1).

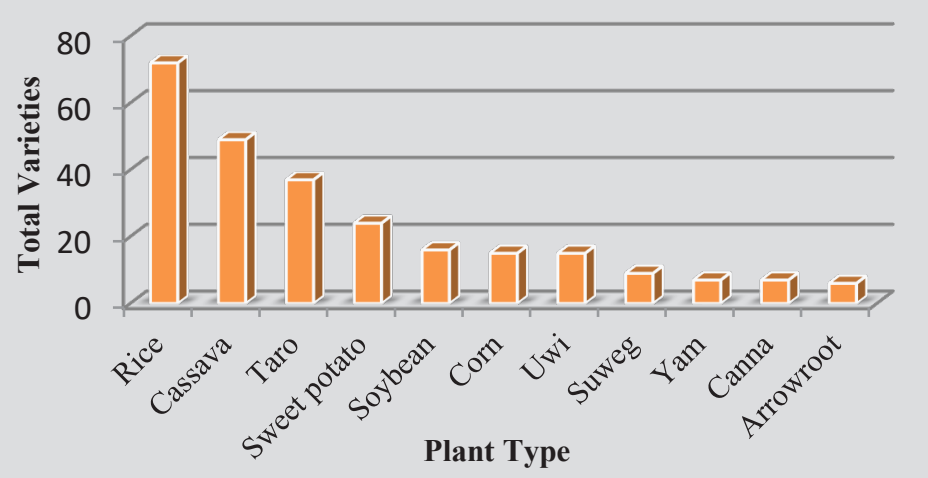

Fig. 1. Composition of local food varieties in Central Java

Local rice was the main food commodity most commonly cultivated in Central Java. The composition of local rice varieties that were identified in both irrigated and dryland agroecosystems included seven red rice (10\%), nine black rice (12\%), and 27 white rice $(38 \%)$. Red and black rice were still maintained by local farmers using cultivation techniques based on their wisdom. Both types of rice were in demand because of their trust in nutritional content. This activity also recorded seventeen varieties of glutinous rice (24\%) which functioned for customary community events. In addition, the Manuk Putih variety $(1 \%)$ which was used as animal feed was also found. Furthermore, the potential genetic resources in three upland rice varieties (4\%) and eight aromatic rice ones $(11 \%)$ were also discovered at the study site. The two rice varieties were a mainstay of local farmers because they have good adaptability to sub-optimal environments, besides quality, delicious and fragrant rice (Fig. 2).

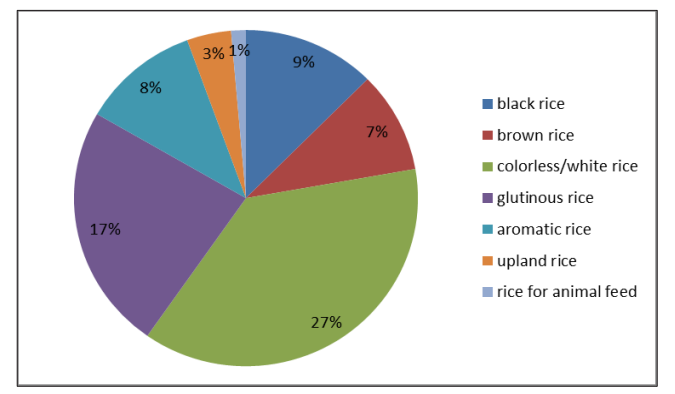

Fig. 2. Composition of local rice varieties in Central Java

Local rice varieties which were successfully inventoried in the study were divided into the popular Indica and Javanica groups. A total of 48 varieties of rice were of the Indica type (66\%). This type of rice has a light green leaf morphology, with leaf width varied. The grain varies from long to short, slender, tends to break more efficiently, and the end of the grain is hairless. The rest were 24 varieties of Javanica rice $(34 \%)$. The character of Javanica rice is its broad light green leaves, and the plant performance is generally high and stiff. Rice grains are long, wide, thick, and not easily broken, and have hairy ends (Fig. 3). 


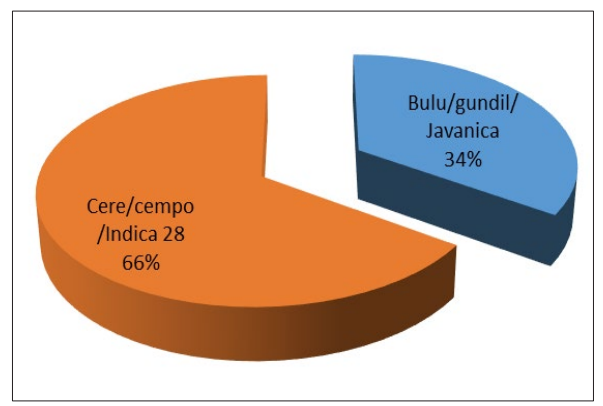

Fig. 3. Composition of local rice types in Central Java

Rice is a major food crop, including in Central Java. The local rice inventory proved that some of the varieties can only be cultivated by farmers in specific regions. These varieties are Pusaka in Tegal, Sirampog in Brebes, Umbul-umbul in Karanganyar, and Bulu Konyal in Banjarnegara. Local varieties are known to be increasingly eroded in population, so they need to be collected and be rejuvenated through in-situ and ex-situ conservation to avoid extinction. The more sources of genotypes available will increase options for plant breeding. Local food crops collection is useful for future breeding program materials.

In-situ is an effort to conserve ecosystems, support and restore the habitat so that populations can develop specific characteristics. Therefore, in-situ conservation management and policies related to genetic resources in wild populations are urgently needed. Besides, it is crucial to create awareness systems to protect biodiversity by involving local communities, government, academic institutions, and farmers as active partners to conserve species [15]. Approaches to in-situ conservation require local supports and have the best chances of success if locally initiated and sustained.

In-situ management of local crops by farmers can conserve varieties, increase genetic diversity, and become an essential element for a sustainable agricultural design. Agroecosystem resource support prevents plant species from being affected or undergoing changes in the genetic structure of varieties managed in the source population. In-situ approaches need local supports to have a chance of success. Promoting awareness of management, monitoring, and evaluation genetic resources also requires financial factors and local benefits [16].

Ex-situ is the protection of components of biodiversity outside their natural habitat. Local cultivation of varieties outside of the original environment could be established in a collection garden or preservation in a genetic bank. Evaluation, purification, rejuvenation, and use of germplasm are required to get a uniform variety. Ex-situ conservation complements sustainable in-situ planting. Due to increasing demand, climate changes, and biotic stresses cause an ex-situ balance of genetic diversity. Ex-situ is very important as a form of guarantee for germplasm used in breeding, plant improvement, and ensuring opportunities for sustainable adaptation. This collection of efforts can generate new resistance and valuable traits for the adaptation and transformation of varieties to climate changes [17]. Local rice varieties can be used for assembling new ones. Local genotype rice sources developed through breeding programs can have the preferred characteristics of farmers and consumers [18]. 


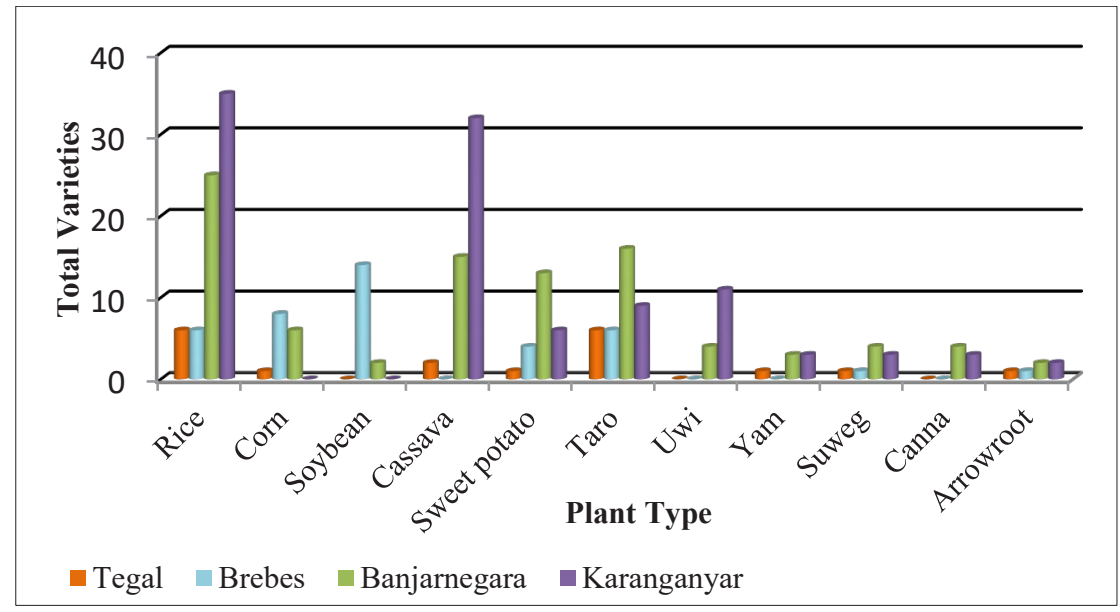

Fig. 4. Composition of local food crops for each region in Central Java

Varieties as a group of plants with certain characteristics and can be clearly distinguished from other groups were still found in rice fields and farmers' yards in Tegal. The varieties found consisted of rice (6), taro (6), cassava (2), and one variety of corn, sweet potato, Amorphophallus paeoniifolius, and arrowroot, respectively. The local varieties inventoried in Brebes included soybean (14). The fourteen varieties of Glycine max are grown by local farmers and the local government trying to develop the potential of these varieties. Cultivation of local soybean, black and white types, was more commonly found in Brebes than in other areas. The exotic black soybeans of Brebes were characterized by dark black seeds. Other varieties in this region were corn (8), rice (6), taro (6), sweet potato (4), Amorphophallus paeoniifolius (1), and arrowroot (1). Local varieties are alternative food for local people through consumption, diversification, and increased value-added of food products (Fig. 4).

In traditional cropping systems, a given variety name was generally known by different designations in each region. Therefore, the diversity associated with local variety names is an unreliable indicator of existing genetic diversity. However, the consistency of the name of the variety is a good indicator of performing the local cultivation system.

Banjarnegara has a steep topography and wavy contours site. The exploration of local food crops in Banjarnegara proved the occurrence of local varieties i.e. rice (25), soybean (2), corn (13), taro (16), cassava (15), sweet potato (6), Dioscorea alata (4), Amorphophallus (4), canna (4), sweet potato (3), and arrowroot (1). Thus, the composition of local food varieties found in Karanganyar included rice (35), cassava (32), and sweet potato (11) (Fig. 4).

The local food varieties in Tegal appeared lower than those in the other three regions (Brebes, Banjarnegara, and Karanganyar). The use of superior varieties seems to have boosted the planting areas of local varieties and only survived in the highlands, dry land, and rainfed land in remote areas which have not been suitable for superior varieties.

Farmers have more concerned with improved varieties because they were influenced by the view that local varieties only produce low yields in longer time periods, resulting in decreased use and conservation of the varieties. However, local variety diversity is required, especially on sub-optimal lands which need specific inputs. Rapid replacement of varieties in monoculture systems in adjacent areas and on a large scale can pose a severe risk of an explosion in the spread of diseases and pests that harm plant growth [7]. 


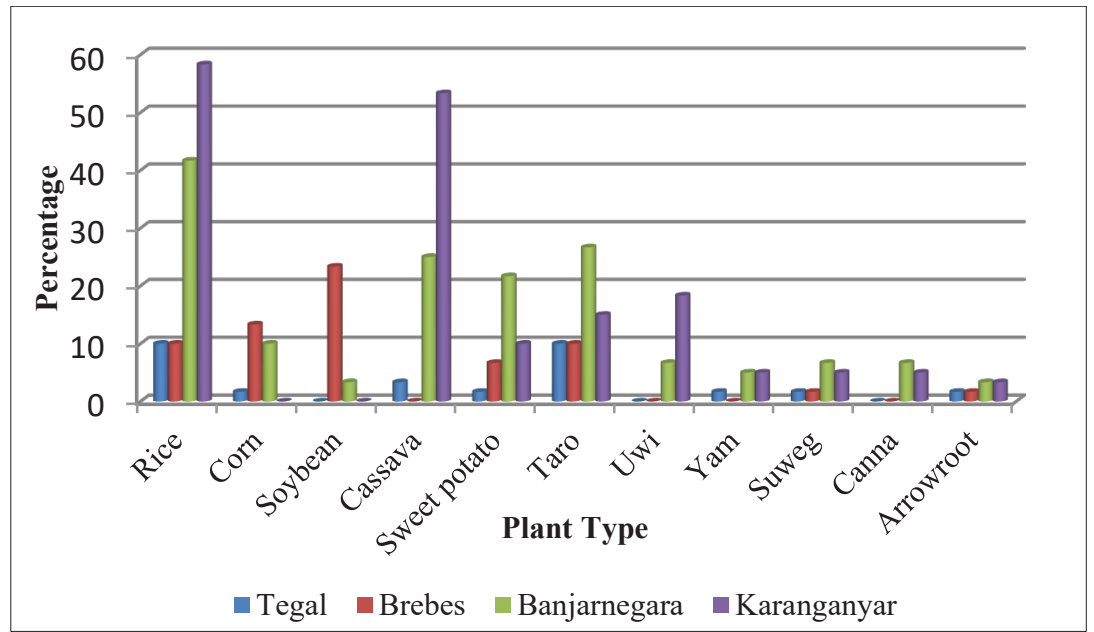

Fig. 5. Frequency of distribution of local food crops for each region in Central Java

The distribution frequency of local food plants was calculated to find the number and coverage of distribution in the selected area in each regency. Frequencies with a 1-25\% percentage value range showed a very narrow distribution in the study area. This distribution was located in Tegal and Brebes for all types of local food crops, namely rice, corn, cassava, sweet potato, taro, Amorphophallus paeoniifolius, and canna. No soybean, Dioscorea alata, and canna were found ( $0 \%$ vale). It means that minimum conservation and cultivation. The frequency values about $26-50 \%$ indicated the limited distribution of local food crops such as rice and taro. The frequencies of these commodities were found in Banjarnegara. The highest distribution frequency value of $58.33 \%$ was indicated by rice farming in Karanganyar with a moderate or even distribution level in each site (Fig. 5). Therefore, farmers in Karanganyar can conserve and have the awareness to continue planting local rice. It means that an indicator that Karanganyar could support efforts to conserve genetic resources and develop location-specific rice cultivation. Local food crops have been recognized by the community as an essential source of alternative nutrition.

\subsection{Diversity of local food crops in Central Java}

The diversity index used to express the abundance of certain species in an area showed that the diversity and similarity of species in one value were represented by the Shannon Diversity Index (H'). This index was based on information theory and averages in predicting randomly selected individuals from a collection of plant species (S). The analysis of the diversity of local food plants showed that Banjarnegara had the largest $\mathrm{H}^{\text {' }}$ value (2.073) compared to other locations. This report showed that Banjarnegara had more local food crops than other areas. The value of H' reached the largest when individuals with the same number of individuals represented all $\mathrm{S}$ and a perfectly even distribution of abundance. The H' values in Karanganyar, Tegal, and Brebes were 1.726, 1.739, and 1.673, respectively (Fig. 6).

The genetic diversity of food plants maintained using local farmers' knowledge in-situ is very important to make sure genetic progress. Agricultural areas can strategically become locations for germplasm conservation. The average diversity of local food plants will increase with the multitude of the species and the distribution of individuals between plant types [19]. 


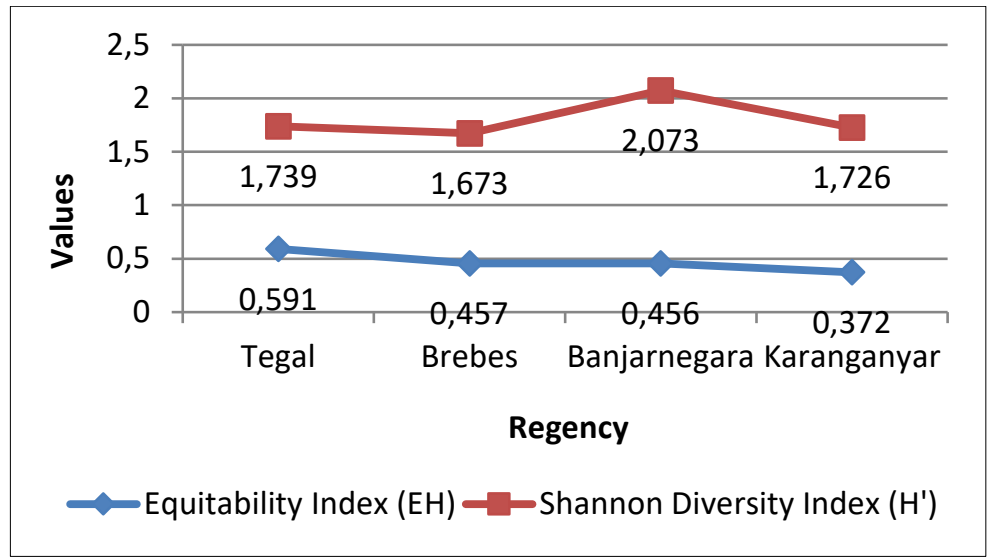

Fig. 6. Shannon Diversity Index and Equitability Index of local food crops in Central Java

The relationship between the Shannon Diversity Index and the Equitability Index can be found clearly in the Tegal. The regency was that the number of varieties in each type of plant is not too many but evenly distributed in each kind of plant. The index value was estimated at less than one and showed equity. There discovered in Tegal, Brebes, Banjarnegara, and Karanganyar regions. This illustrates the dominance of certain type of local food plants. Meanwhile, Karanganyar provides the smallest Equitability Index (0.372) which indicated that this area it's only dominated by rice. This average will increase as the number of species increases and distribute individuals between species become evenly distributed (Fig. 6).

Table 2. Sorensen Similarity Coefficient (SC) for local food crops in Central Java

\begin{tabular}{|l|c|c|c|c|}
\hline \multicolumn{1}{|c|}{ SC } & Tegal & Brebes & Banjarnegara & Karanganyar \\
\hline Tegal & 1 & 0,271 & 0.142 & 0.130 \\
\hline Brebes & & 1 & 0.104 & 0.097 \\
\hline Banjarnegara & & & 1 & 0.111 \\
\hline Karanganyar & & & & 1 \\
\hline
\end{tabular}

The Sorensen Similarity Coefficient was used to assess the composition of plant species in one area compared to another. The similarity coefficient between regions showed that it was smaller than $30 \%$. This value was very low and proved relationship between habitat types and areas based on different agro-ecological zones. Brebes and Tegal showed the greatest value $(0.271)$ and describe the same geographic location in the north coastal area with high average temperatures and similar characteristics of farmers. The smallest this value was between the Brebes and Karanganyar areas (0.097). It suggested an association of geographical conditions (topography, altitude, temperature, rainfall, and soil type). The local plant genetic resources were unique, exotic, and environmentally specific (Table 2).

\section{Conclusions}

Inventories programs in Central Java at four Regencies (Tegal, Brebes, Banjarnegara, and Karanganyar) showed a wealth of genetic resources and diversity of local food crops. Exploration of farmer's land illustrated the composition and levels of similarity of local varieties between regions. Policy recommendations for protecting genetic resources are needed to support the diversity of local food plants. In addition, research development that 
uses local varieties as materials for plant breeding needs to be encouraged to make them more useful as sources of functional food.

Acknowledgments. Special thanks to the Assessment Institute for Agricultural Technology of Central Java for funding the research. Appreciate the reviewers for valuable input so that the paper can be published.

\section{References}

1. J.M. Galeana-Pizaña, S. Couturier, D. Figueroa, A.D. Jiménez, Agric. Syst. 190 $103091(2021)$

2. A.A. Hatab, M.E.R. Cavinato, A. Lindemer, C.J. Lagerkvist, Cities. 94, 129-142 (2019)

3. R.C. Denny, S.T. Marquart-Pyatt, A. Ligmann-Zielinska, L.S. Olabisi, L. Rivers, J. Du, L.S.O. Liverpool-Tasie, Environ. Syst. Decis. 38, 1, 6-22 (2018)

4. S.N. Eriksen, Acta Agric. Scand. B Soil Plant Sci. 63, 47, 552013 (2013)

5. X. Cirera, E, Masset. Philos. Trans. R. Soc. Lond. B. Biol. Sci. 365, 2821-2834 (2010)

6. S. Jian-Chang, C. Gui-Lan, M. Jing, C. Yao-Feng, H. Long-Zhi, Genet. Resour. Crop Evol. 59, 1611-1623 (2012)

7. P.C. Kesavan, M.S. Swaminathan, Philos. Trans. R. Soc. 363, 877-891 (2008)

8. P. Batáry, A. Báldi, J. Ekroos, R. Gallé, I. Grass, T. Tscharntke, Biol. Futura. 71, 1-2 9-18 (2020)

9. M.A. Altieri, F.R. Funes-Monzote, P. Petersen, Agron. Sustain. Dev. 321, 13 (2012)

10. U. Triastuti, E. Tedjakusuma, Sriyanti, M. Girianna, W. Darajati, B. Hernowo, Y. Hidayat, B. Prihartono, M. Simarmata, M. Azdan, A. Armawikarta, B. Hidayat, Mintzer, Irving, Indonesia climate change sectoral roadmap ICCSR synthesis report (BAPPENAS, Jakarta, 2009)

11. J.R.N. Johanita, M.G. Taylor, H. Ferruzzi, Debelo, Comprehensive reviews in food science and food safety (Wiley, New Jersey, 2020)

12. Ministry of Agriculture, Guidelines for inventory and/or collection of plant genetic resources in Indonesia (Ministry of Agriculture, Bogor, 2013)

13. H. Tuomisto, Echography. 33, 2-22 (2010)

14. J. Wang, C. Zou, H. Ren, W.J. Duan, J. Trop. For. Sci. 21, 3, 210-217 (2009)

15. L. Gao, D. Li, X. Wu, W. Chen, Z. Huang, X. Wei, Am. J. Plant Sci. 3, 854-868 (2012)

16. J. Donazzolo, V.M. Stefenon, M.P. Guerra, R.O. Nodari, Sci. Hortic. 259, 108826 (2020)

17. J. Lidwell-Durnin, A. Lapthorn, Glob. Food Sec. 26, 100446 (2020)

18. V.E. Aristya, Taryono, Y.A. Trisyono, J.H. Mulyo, IOP Conf. Ser.: Earth Environ. Sci. 686, 012056 (2021)

19. K.L. dos Santos, J. Donazzolo, R.P. Guries, N. Peroni, R.O. Nodari, Agroecol. Sustain. Food Syst. 42, 4, 432-447 (2018) 